\title{
Retracted: Nontraumatic Lesions of the Clavicle in a Paediatric Population: Incidence and Management
}

\author{
International Scholarly Research Notices
}

Received 19 March 2015; Accepted 19 March 2015

Copyright (C) 2015 International Scholarly Research Notices. This is an open access article distributed under the Creative Commons Attribution License, which permits unrestricted use, distribution, and reproduction in any medium, provided the original work is properly cited.

The paper titled "Nontraumatic Lesions of the Clavicle in a Paediatric Population: Incidence and Management" [1], has been retracted upon receiving the submitting author's confirmation that the paper was submitted without including Dr. Iain Campbell's name among the paper's authors, despite his contribution to the scientific content of the paper.

\section{References}

[1] N. D. Clement, G. Nicol, and D. E. Porter, "Nontraumatic lesions of the clavicle in a paediatric population: incidence and management," International Scholarly Research Notices, vol. 2014, 5 pages, 2014. 